Original Article

\title{
THE OPTIMIZATION OF HPLC FOR QUANTITATIVE ANALYSIS OF ACID ORANGE 7 AND SUDAN II IN COSMETIC PRODUCTS USING BOX BEHNKEN DESIGN
}

\author{
NOVALINA B. R. PURBA1,2, ABDUL ROHMAN ${ }^{*}$, , SUDIBYO MARTONO
}

1Department of Pharmaceutical Chemistry, Faculty of Pharmacy, Universitas Gadjah Mada, Yogyakarta, ${ }^{2}$ The National Agency of Drug and Food Control, District of Denpasar 80235, Bali Republic of Indonesia

Email: abdul_kimfar@ugm.ac.id

Received: 11 Dec 2018, Revised and Accepted: 30 Jan 2019

\section{ABSTRACT}

Objective: The objective of this study was to optimize high-performance liquid chromatography (HPLC) method for the determination of acid orange 7 (AO7) and sudan II (SII) in blusher product based on response surface methodology using box behnken design (BBD) approach.

Methods: Some factors responsible for HPLC separation including column temperature, mobile phase composition, flow rate were optimized using BBD. The responses evaluated were peak area, retention time, and tailing factor. A07 and SII in blusher product has different properties, therefore both analytes were analysed using C18 column (Thermo Synergy Gold $250 \mathrm{~mm}$ x $4.6 \mathrm{~mm}$ i.d.,5 $\mu \mathrm{m}$ ) using Shimadzu LC $20 \mathrm{AD}$ chromatograph equipped with photo-diode array (PDA) detector at 300-650 nm. The mobile phase used was acetonitrile-water (1:1 v/v), and acetonitrile composition was optimized at 35-50\% for separation A07 (ACN1), and $80-90 \%$ for SII (ACN2), delivered at the flow rate of 0.9-1 ml/min, using column temperature at $30-40^{\circ} \mathrm{C}$.

Results: BBD showed that separation of A07 was influenced by the concentration of ACN1, flow rate and column temperature. These factors affected retention time, peak area, and tailing factor with peak area was the most significant. Tailing factor was not significantly affected by each factor, and retention time was slightly effected. Otherwise, Sudan II was affected by all these factors except ACN1. The optimal condition obtained based BBD was ACN1 43\%, ACN2 90\%, the flow rate of $0.9 \mathrm{ml} / \mathrm{min}$ and a column temperature of $40{ }^{\circ} \mathrm{C}$.

Conclusion: BBD can be used to get optimum condition for analysis of AO7 and SII in blusher product.

Keywords: Acid orange 7, Sudan II, HPLC, BBD, Blusher

(C) 2019 The Authors. Published by Innovare Academic Sciences Pvt Ltd. This is an open access article under the CC BY license (http://creativecommons.org/licenses/by/4.0/) DOI: http://dx.doi.org/10.22159/ijap.2019v11i2.31285

\section{INTRODUCTION}

Dyes is the most important additive component in cosmetics industry to improve personal appearance [1]. Acid orange 7 (A07) and sudan II (fig. 1) are azo dyes. AO7 is allowed in cosmetics product except if it was used around eyes. Sudan II (SII) is a forbidden dyes. Because of its similarity colour, A07 is often replaced by sudan II [2]. A07 and SII are harmful for longterm use $[3,4]$. Therefore, analytical methods for analysing A07 and SII must be developed in order to ensure the cosmetic safety.

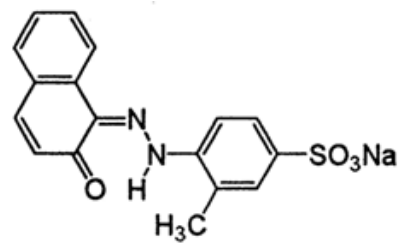

Acid Orange 7<smiles>Cc1ccc(/N=N/c2c(O)ccc3ccccc23)c(C)c1</smiles>

Sudan II

Fig. 1: The chemical structures of acid orange 7 (A07) and sudan II (SII)

Different solubility of A07 and SII make big challenge in the separation of both compounds simultaneously. Some methods have been reported for determination of $\mathrm{AO} 7$ and SII individually which are included ELISA, [5], UV-Vis [6], FTIR [7], HPTLC [8], LC/GC-MS [9, 10], HPLC [11-15]. These methods consume time and not effective, therefore optimization method HPLC for simultaneous analysis of A07 and SII using experimental design is very interesting. Experimental design can predict optimum condition in short experiment and time. This design can determine the correlation between factors and respons (output) that are resulted in the experiment process [16].

\section{MATERIALS AND METHODS}

Blush products were obtained from local markets in Yogyakarta. Reference standars of acid orange 7 (CI 15510, Control Number: BR0114304), sudan II (CI 12140, Control Number: 113034) were acquired from the national agency of drug and food control (NADFC) of Republic of Indonesia. All solvents used for mobile phase were of HPLC grade and obtained from E. Merck (Darmstadt, Germany). Aquabidest was obtained from Ikapharmindo (Indonesia).

\section{Preparation of reference standards}

An approximately of $5.00 \mathrm{mg}$ of each A07 and SII was accurately weighed using analytical balance (Metler Toledo MX5) with a sensitivity of $0.01 \mathrm{mg}$ and was added into volumetric flask $5 \mathrm{ml}$. A07 was dissolved in $3 \mathrm{ml}$ methanol, sonicated using sonicator (Elma ultrasonic, Germany) for 5 minute, and made to volume with methanol $(5 \mathrm{ml})$ to get the solution with the concentration of 1000 $\mu \mathrm{g} / \mathrm{ml}$. SII was dissolved in $1 \mathrm{ml}$ acetonitrile, added with $2 \mathrm{ml}$ methanol, sonicated for 5 minute and made to volume $5 \mathrm{ml}$ with methanol to get the solution with the concentration of $1000 \mu \mathrm{g} / \mathrm{ml}$. 


\section{Preparation of samples}

An approximately of $100.0 \mathrm{mg}$ of blush cosmetic products was accurately weighed using analytical balance (Metler Toledo MX5)with the sensitivity of $0.1 \mathrm{mg}$, added with $1.0 \mathrm{ml}$ of each standard solutions (AO7 and SII), added with $1 \mathrm{ml}$ acetonitrile, sonicated for 5 minute, and added with methanol to volume $5 \mathrm{ml}$. The solution was filtered with PTFE $0.45 \mu \mathrm{m}$. In HPLC vial, $125 \mu \mathrm{l}$ of this solution was added with $875 \mu \mathrm{l}$ of acetonitrile: methanol $(1: 1 \mathrm{v} / \mathrm{v})$. The solution was injected into HPLC system.

\section{HPLC instrumentation}

A07 and SII were analysed using chromatograph of Shimadzu LC 20AD chromatograph equipped with photo-diode array (PDA) (Shimadzu LC 20AD, M20A PDA Detector) at wavelength of 300-650 nm. Separation of analytes was performed using C18 column (Thermo Synergy Gold 250 $\mathrm{mm} \times 4.6 \mathrm{~mm}$ i.d., $5 \mu \mathrm{m}$ ). The mobile phase was modified from method of determining sudan dyes [12], used acetonitrile-water as solvent $[1: 1$ $\mathrm{v} / \mathrm{v}$ ), the composition of acetonitrile was optimized at $35-50 \%$ for separation AO7 (ACN 1), 80-90\% for SII (ACN 2), delivered at flow rate of $0.9-1 \mathrm{ml} / \mathrm{min}$, using column temperature of $30-40^{\circ} \mathrm{C}$.

\section{Experimental design using BBD}

Most experimental design technique used is based on response surface methodology (RSM), a optimization based on fit of a polynomial equation to data experiment $[17,18]$. Symmetrical design of RSM, namely central composite design (CCD) and box behnken design (BBD) are frequently used in HPLC method optimization because they can resolve HPLC separation-related problems which the number of factors is higher than 2 [18]. CCD and BBD have difference of selection experimental point, variables number, as well as number of run and block [19]. In this study, separation of $\mathrm{AO7}$ and SII, four factors, also known as independent variables namely acetonitrile concentration for separation of A07 (ACN1)(X1), acetonitrile concentration for separation of SII (ACN2) (X2), flow rate (X3), and column temperature (X4) were used. While, the responses, known as dependent variables evaluated included retention time A07 and SII (Y1 and Y2), peak area A07 and SII (Y3 and Y4), tailing factor AO7 and SII (Y5 and Y6).

\section{Data analysis}

All experiments using BBD along with statistical parameters were performed using Design-Expert version 8.0.4.1. The responses evaluated were retention time, peak area, tailing factor. of A07 and SII. Factors (independent variables) significantly affected the responses (dependent variables) if $R^{2} \geq 0.8$ and Adjusted $R^{2}>0.8$. The difference between Predicted $\mathrm{R}^{2}$ with the Adjusted $\mathrm{R}^{2}$ must be less than 0.2. The confirmation of optimal method was performed using six injection replicates. The statistical test of independent t-test was used for comparing results obtained from BBD and from actual experiments was carried out using Minitab software version 17 (Minitab Corp., USA).

Table 1: Box-Behnken design using dependent variables of concentration of acetonitrile 1 (\%) (X1), concentration of acetonitrile 2 (\%) (X2), flow rate (X3) and column temperature (X4) with response variables of retention time A07 (Y1), retention time A07 (Y2), peak area A07 (Y3), peak area SII (Y4), tailing factor A07 (Y5) and tailing factor SII (Y6) used in HPLC optimization for separation of Acid Orange 7 (A01) and sudan II (SII)

\begin{tabular}{|c|c|c|c|c|c|c|c|c|c|c|c|}
\hline \multirow[t]{2}{*}{ Std } & \multirow[t]{2}{*}{ Run } & \multicolumn{4}{|c|}{ Dependent variables } & \multicolumn{6}{|l|}{ Responses } \\
\hline & & $\begin{array}{l}\text { Conc. } \\
\text { ACN } 1 \\
\text { (\%) } \\
\text { (X1) }\end{array}$ & $\begin{array}{l}\text { Conc. } \\
\text { ACN } 2 \\
(\%) \\
(\mathrm{X} 2)\end{array}$ & $\begin{array}{l}\text { Flow rate } \\
\text { (ml/min) } \\
\text { (X3) }\end{array}$ & $\begin{array}{l}\text { Column } \\
\text { Temp. }\left({ }^{\circ} \mathrm{C}\right) \\
(\mathrm{X} 4)\end{array}$ & $\begin{array}{l}\text { Retention } \\
\text { time A07 } \\
\text { (Y1) }\end{array}$ & $\begin{array}{l}\text { Retention } \\
\text { time SII (Y2) }\end{array}$ & $\begin{array}{l}\text { Area } \\
\text { A07 } \\
\text { (Y3) }\end{array}$ & $\begin{array}{l}\text { Area SII } \\
\text { (Y4) }\end{array}$ & $\begin{array}{l}\text { TF } \\
\text { A07 } \\
\text { (Y5) }\end{array}$ & $\begin{array}{l}\text { TF SII } \\
\text { (Y6) }\end{array}$ \\
\hline 29 & 1 & 42.5 & 85 & 1 & 35 & 2.551 & 14.075 & 718647 & 761589 & 0.857 & 1.031 \\
\hline 28 & 2 & 42.5 & 85 & 1 & 35 & 2.495 & 14.130 & 710606 & 761514 & 0.726 & 1.028 \\
\hline 27 & 3 & 42.5 & 85 & 1 & 35 & 2.391 & 14.134 & 706873 & 761573 & 0.810 & 1.025 \\
\hline 14 & 4 & 42.5 & 90 & 0.9 & 35 & 2.577 & 14.179 & 783104 & 826350 & 1.026 & 1.048 \\
\hline 20 & 5 & 50 & 85 & 1.1 & 35 & 1.991 & 12.636 & 629380 & 691823 & 0.800 & 1.035 \\
\hline 2 & 6 & 50 & 80 & 1 & 35 & 2.158 & 15.339 & 690442 & 773393 & 0.771 & 1.001 \\
\hline 10 & 7 & 50 & 85 & 1 & 30 & 2.458 & 14.286 & 691074 & 761217 & 0.849 & 1.030 \\
\hline 9 & 8 & 35 & 85 & 1 & 30 & 3.106 & 15.045 & 709254 & 760680 & 0.617 & 1.026 \\
\hline 3 & 9 & 35 & 90 & 1 & 35 & 2.699 & 13.261 & 716202 & 743710 & 0.709 & 1.055 \\
\hline 11 & 10 & 35 & 85 & 1 & 40 & 2.183 & 14.012 & 677197 & 760764 & 0.682 & 1.017 \\
\hline 8 & 11 & 42.5 & 85 & 1.1 & 40 & 1.836 & 12.631 & 638040 & 691491 & 0.709 & 1.018 \\
\hline 19 & 12 & 35 & 85 & 1.1 & 35 & 2.406 & 13.314 & 654414 & 686654 & 0.654 & 1.033 \\
\hline 23 & 13 & 42.5 & 80 & 1 & 40 & 1.975 & 15.245 & 691065 & 770904 & 0.779 & 0.985 \\
\hline 6 & 14 & 42.5 & 85 & 1.1 & 30 & 2.404 & 13.585 & 650290 & 692914 & 0.792 & 1.036 \\
\hline 17 & 15 & 35 & 85 & 0.9 & 35 & 2.634 & 15.808 & 775329 & 846130 & 0.646 & 1.017 \\
\hline 18 & 16 & 50 & 85 & 0.9 & 35 & 2.257 & 14.983 & 760805 & 840086 & 0.767 & 1.023 \\
\hline 12 & 17 & 50 & 85 & 1 & 40 & 1.858 & 13.232 & 685957 & 760518 & 0.763 & 1.013 \\
\hline 25 & 18 & 42.5 & 85 & 1 & 35 & 2.125 & 14.120 & 697755 & 758976 & 0.763 & 1.017 \\
\hline 16 & 19 & 42.5 & 90 & 1.1 & 35 & 1.903 & 11.982 & 637067 & 676598 & 0.731 & 1.051 \\
\hline 1 & 20 & 35 & 80 & 1 & 35 & 2.286 & 16.215 & 678082 & 770621 & 0.681 & 0.994 \\
\hline 26 & 21 & 42.5 & 85 & 1 & 35 & 2.060 & 14.138 & 701493 & 759523 & 0.692 & 1.020 \\
\hline 5 & 22 & 42.5 & 85 & 0.9 & 30 & 2.729 & 16.085 & 778922 & 842236 & 0.905 & 1.027 \\
\hline 22 & 23 & 42.5 & 90 & 1 & 30 & 2.596 & 13.439 & 709574 & 744095 & 0.747 & 1.060 \\
\hline 21 & 24 & 42.5 & 80 & 1 & 30 & 2.494 & 16.614 & 711806 & 772956 & 0.743 & 1.006 \\
\hline 4 & 25 & 50 & 90 & 1 & 35 & 1.965 & 12.565 & 690365 & 743483 & 0.817 & 1.049 \\
\hline 13 & 26 & 42.5 & 80 & 0.9 & 35 & 2.178 & 17.461 & 766545 & 857715 & 0.853 & 0.986 \\
\hline 24 & 27 & 42.5 & 90 & 1 & 40 & 1.942 & 12.573 & 686926 & 745445 & 0.860 & 1.038 \\
\hline 7 & 28 & 42.5 & 85 & 0.9 & 40 & 2.078 & 14.984 & 754334 & 843051 & 0.938 & 1.008 \\
\hline 15 & 29 & 42.5 & 80 & 1.1 & 35 & 1.792 & 14.690 & 635316 & 702640 & 0.713 & 0.987 \\
\hline
\end{tabular}

\section{RESULTS AND DISCUSSION}

HPLC is the most method used for separation of dyes because of its sensitivity, precision, accuracy, time efficiency, low cost and robust [20]. The different polarity between $\mathrm{AO}$ and SII might be cope by gradient elution method, therefore the separation of A07 and SII are rather difficult. Reversed phase (C18) column did not retain A07 in the high concentration of non-polar solvent, while the high concentration of polar solvent such as water could increase its binding with the stationary phase, therefore an experimental design approach was used. Box- 
behnken design (BBD) was used for HPLC separation of AO7 and SII. BBD was performed using 29 runs, applying 4 independent variables (factors) namely concentration of acetonitrile 1 (\%) (X1), concentration of acetonitrile $2(\%)(\mathrm{X} 2)$, flow rate (X3) and column temperature (X4) along with response variables of retention time A07 (Y1), retention time A07 (Y2), peak area A07 (Y3), peak area SII (Y4), tailing factor A07 (Y5) and tailing factor SII (Y6). BBD using these factors and responses resulted during optimization were compiled in table 1.

Based on analysis of variance (ANOVA) results, the equation obtained using $\mathrm{X}_{1}, \mathrm{X}_{2}, \mathrm{X}_{3}$, and $\mathrm{X}_{4}$ as independent variables with the retention time of $\mathrm{AO7}\left(\mathrm{Y}_{1}\right)$ as response was:

$\mathrm{Y}_{1}=6.4401-2.92 \times 10^{-2} \mathrm{X}_{1}-1.33 \times 10^{-2} \mathrm{X}_{2}-1.77 \mathrm{X}_{3}-0.07 \mathrm{X}_{4}$
The statistic results revealed that Adj. $\mathrm{R}^{2}$ obtained was $<0.8$, which indicated that the experimental model was not good fit using polynomial equation [21]. Difference Predicted $\mathrm{R}^{2}$ with the Adjusted $\mathrm{R}^{2}$ in all respons less than 0.2. Eq.1 informed that that variables of the concentration of acetonitrile $1(\%)(\mathrm{X} 1)$, the concentration of acetonitrile $2(\%)(\mathrm{X} 2)$, flow rate (X3) and column temperature (X4) have a negative effect on the retention time of A07.

The contour plot showed an interaction between factors [21]. Contour plot of retention time SII along with 3D surface graph was shown in fig. 2. Based on ANOVA results, variables of $\mathrm{X}_{1}, \mathrm{X}_{2}, \mathrm{X}_{3}$ and $\mathrm{X}_{4}$, as well as an interaction between $\mathrm{X}_{1}$ and $\mathrm{X}_{3}, \mathrm{X}_{1}$ and $\mathrm{X}_{4}, \mathrm{X}_{3}$ and $\mathrm{X}_{4}$ in linear form, contributed significantly for response of $Y_{1}(P<0.05)$. But, the interaction between $\mathrm{X}_{2}$ and $\mathrm{X}_{1}, \mathrm{X}_{3}, \mathrm{X}_{4}$ did not contributed significantly to retention time of SII.
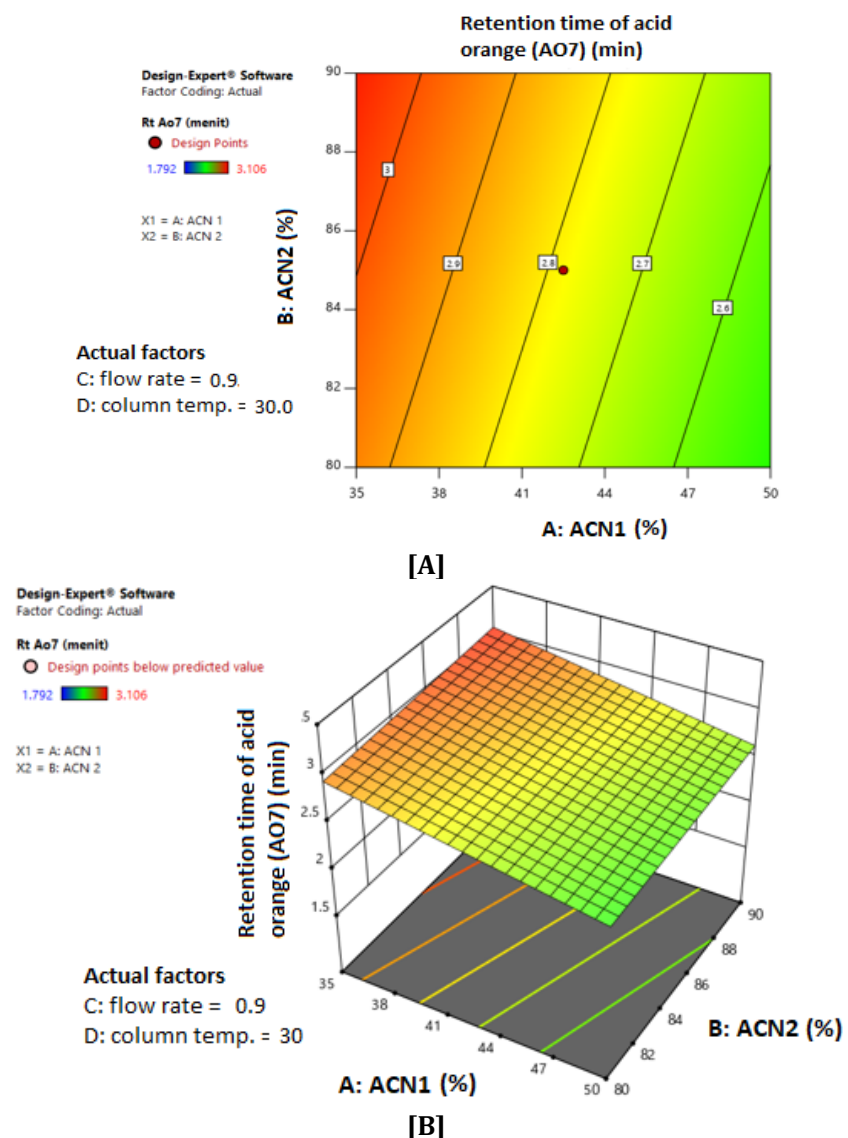

[B]

Fig. 2: The contour plot of Retention time of acid orange 7 (A07) [A] and 3D surface graph of retention time of A07 [B] as a results of variables of concentration of acetonitrile 1 (\%) (ACN1), concentration of acetonitrile 2 (\%) (ACN2), flow rate and column temperature

Similarly, the equation for retention time SII $\left(\mathrm{Y}_{2}\right)$ using multiple linear regression were:

$1 / \mathrm{Y}_{2}=-0.237-9.80 \times 10^{-4} \mathrm{X}_{1}+5.19 \times 10^{-3} \mathrm{X}_{2}-1.93 \times 10^{-2} \mathrm{X}_{3}+7.30 \times 10^{-4} \mathrm{X}_{4}+$ $04.00 \times 10^{-6} \mathrm{X}_{1} \mathrm{X}_{2}+1.80 \times 10^{-4} \mathrm{X}_{1} \mathrm{X}_{3}+4.95 \times 10^{-5} \mathrm{X}_{1} \mathrm{X}_{4}+1.06 \times 10^{-3} \mathrm{X}_{2} \mathrm{X}_{3}-$ $0.000002 .79 \times 10^{-6} \mathrm{X}_{2} \mathrm{X}_{4}+4.9 \times 10^{-4} \mathrm{X}_{3} \mathrm{X}_{4}+0.000006 .21 \times 10^{-6} \mathrm{X}_{1}^{2}-2.90 \times 10$ ${ }^{5} \mathrm{X}_{2}{ }^{2}-0.018 \mathrm{X}_{3}{ }^{2}-9.47 \times 10^{-6} \mathrm{X}_{4}{ }^{2}$ (Adj. $\mathrm{R}^{2}$ of 0.9995) (Eq.2).

The contour plot along with along with 3D surface graph of the retention time of SII was shown in fig. 3. Statistic parameter of $Y_{2}$ revealed adjusted $\mathrm{R}^{2}$ (Adj. $\mathrm{R}^{2}$ ) was $>0.8$ (acceptable) [21] exhibiting that the experimental model was a good fit using the polynomial equation. Based on ANOVA results in variables of $X_{1}, X_{2}, X_{3}$ and $X_{4}$, as well as an interaction between $X_{2}$ and $X_{3}, X_{4}$, quadratic form of $X_{2}$ and $\mathrm{X}_{4}$ contributed significantly for the response of $Y_{2}(P<0.05)$. The interactions of $\mathrm{X}_{1}-\mathrm{X}_{2}$, and $\mathrm{X}_{3}-\mathrm{X}_{4}$ were not significant to $\mathrm{Y}_{2}$ response
$(\mathrm{P}>0.05)$.

Equation 3 revealed the response of peak area Acid Orange $7\left(\mathrm{Y}_{3}\right)$. The statistic results for $Y_{3}$ informed that adj. $R^{2}$ was $>0.8$. The variables of $X_{1}, X_{2}, X_{3}$ and $X_{4}$, as well as an interaction between $X_{1}$ and $X_{3}$, linear form of $X_{1}$ and $X_{3}$ contributed significantly for the response of $\mathrm{Y}_{3} \quad(\mathrm{P}<0.05)$. The variables of $\mathrm{X} 1$ and $\mathrm{X} 2$ affected positively, meaning that the increased levels of concentration of acetonitrile 1 (\%) (X1) and concentration of acetonitrile 2 (\%) (X2) would increase peak area of A07 (increased sensitivity), while the increased levels of flow rate (X3) and column temperature (X4) could decreased peak area. The contour plot along with along with 3D surface graph of the peak area of A07 was shown in fig. 4.

$\mathrm{Y}_{3}=1.3738 \quad \mathrm{x} \quad 10^{-3}+693.94 \quad \mathrm{x} \quad 10^{-3} \mathrm{X}_{1}+833.03 \mathrm{X}_{2}-654443.33 \mathrm{X}_{3}-$ 1956.68X 4 (Adj. $\mathrm{R}^{2}$ of 0.9463) (Eq. 3) 
[A]

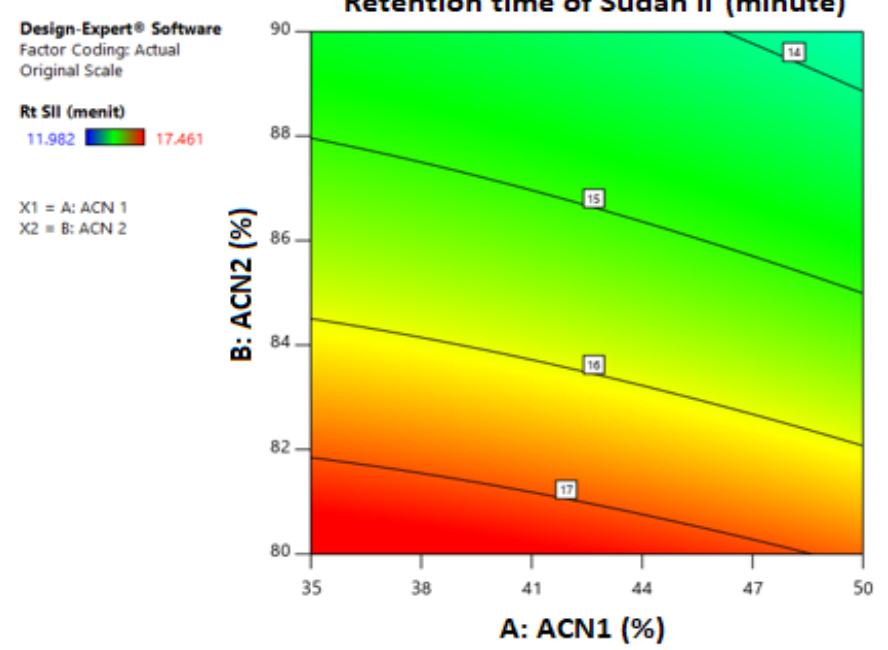

Actual factors

C: flow rate $=0.9$

D: column temperature $=34.8$

[B]
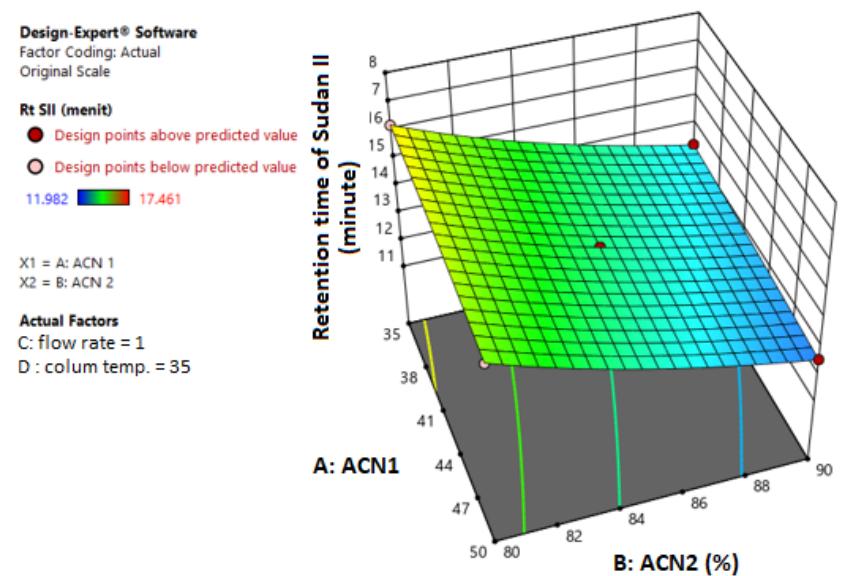

Fig. 3: The contour plot of retention time of Sudan II 7 (SII) [A] and 3D surface graph of retention time of SII [B] as a results of variables of concentration of acetonitrile $1(\%)(\mathrm{ACN} 1)$, concentration of acetonitrile $2(\%)(\mathrm{ACN} 2)$, flow rate and column temperature

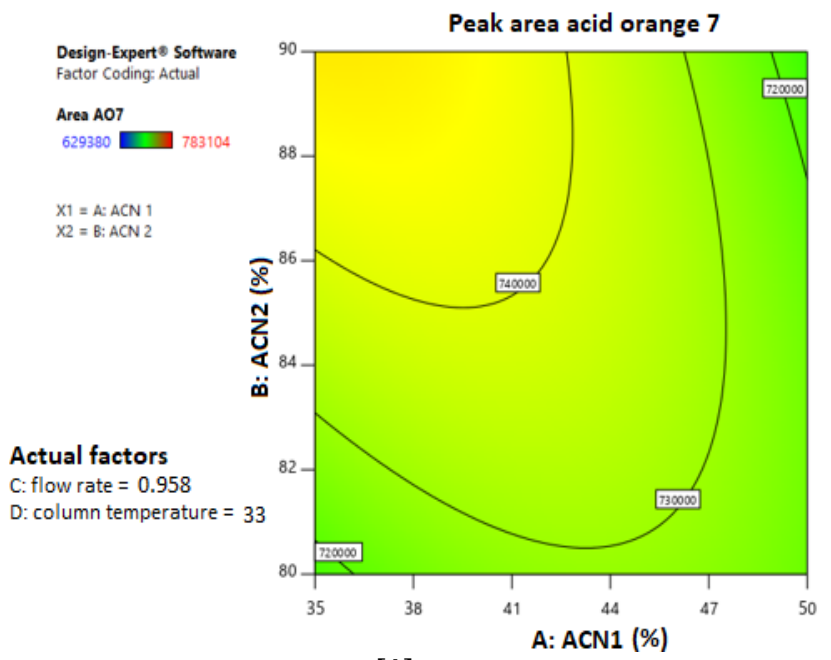

[A]

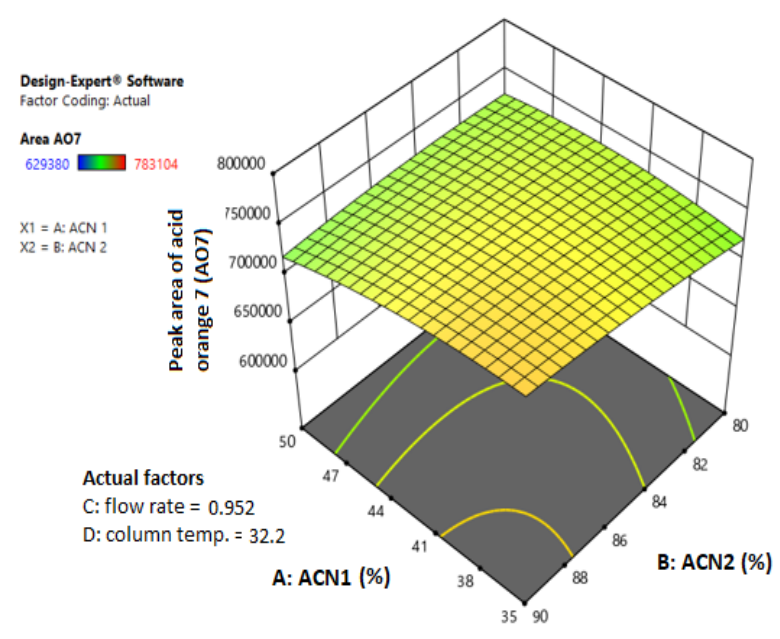

[B]

Fig. 4: The contour plot of peak area of acid orange 7 (A07) [A] and 3D surface graph [B] as a results of variables of the concentration of acetonitrile 1 (\%) (ACN1), a concentration of acetonitrile 2 (\%) (ACN2), flow rate and column temperature 
The equation 4 showed the correlation between the response of peak area of Sudan II (SII) and independent variables of X1, X2, X3 and $\mathrm{X} 4$ along with its interaction.

The statistic results for Y4 showed that Adj. $\mathrm{R}^{2}$ obtained was in the acceptable limits [21]. The ANOVA results revealed that variables of $\mathrm{X}_{1}, \mathrm{X}_{2}, \mathrm{X}_{3}$ and $\mathrm{X}_{4}$, as well as an interaction between
$X_{2}-X_{3}$, quadratic form $X_{2}$ and $X_{3}$ contributed significantly for the response of $\mathrm{Y}_{4}(\mathrm{P}<0.05)$. The interaction of $\mathrm{X}_{1}$ with $\mathrm{X}_{2}, \mathrm{X}_{3}, \mathrm{X}_{4}$ and between $X_{2}$ and $X_{4}$ did not contributed significantly to $Y_{4}$ response.

The contour plot along with along with 3D surface graph of the peak area of SII was shown in fig. 5.

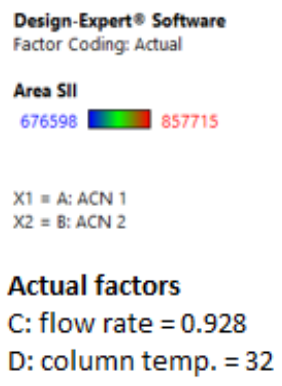

C: flow rate $=0.928$

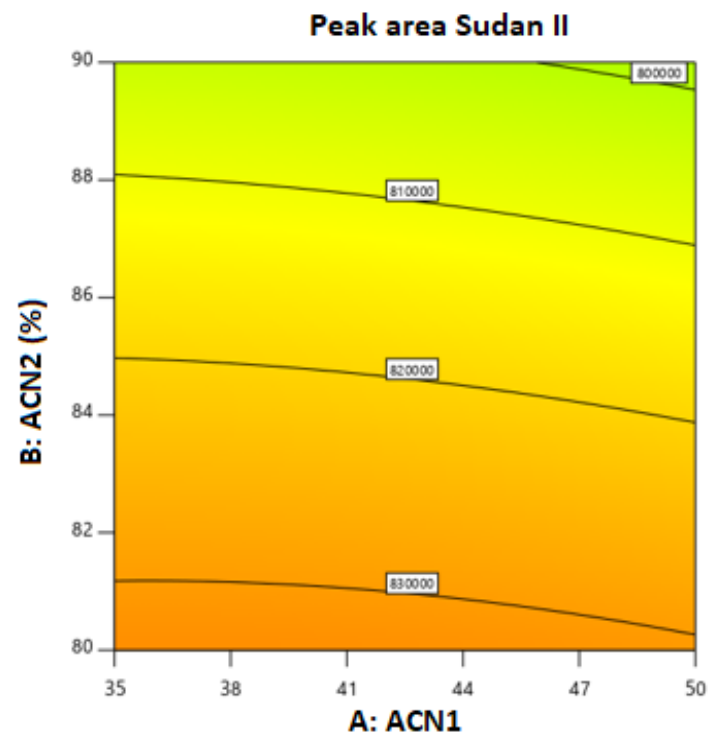

[A]

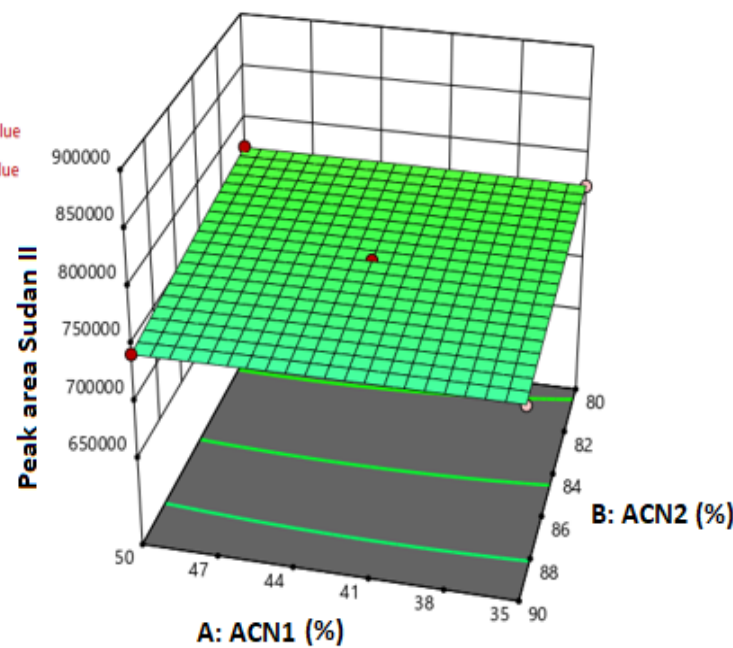

[B]

Fig. 5: The contour plot of peak are of sudan II (SII) [A] and 3D surface graph of SII [B] as a results of variables of the concentration of acetonitrile $1(\%)(A C N 1)$, the concentration of acetonitrile 2 (\%) (ACN2), flow rate and column temperature

\begin{abstract}
$\mathrm{Y}_{4}=7.61 \quad \mathrm{X} \quad 10^{-8}+163.42 \mathrm{X}_{1}-14045.67 \mathrm{X}_{2}-76120.67 \mathrm{X}_{3}-160.42 \mathrm{X}_{4}$ $749.75 \mathrm{X}_{1} \mathrm{X}_{2+} \quad 2803.25 \mathrm{X}_{1} \mathrm{X}_{3-}-195.75 \mathrm{X}_{1} \mathrm{X}_{4+} 1330.75 \mathrm{X}_{2} \mathrm{X}_{3+} 850.50 \mathrm{X}_{2} \mathrm{X}_{4-}$ 559.50X $\mathrm{X}_{4-6}-660.71 \mathrm{X}_{1}^{2}-2056.83 \mathrm{X}_{2}^{2}+6665.42 \mathrm{X}_{3}^{2}+238.29 \mathrm{X}_{4}^{2}$ (Adj. $\mathrm{R}^{2}$ of 0.9995)(Eq. 4)
\end{abstract}

The equations 5 and 6 corresponded to the response of tailing factor of $\mathrm{AO7}\left(\mathrm{Y}_{5}\right)$ and SII $\left(\mathrm{Y}_{6}\right)$. The statistic results for Y5 revealed that Adj. $R^{2}$ obtained was $<0.8$, which was not acceptable [18]. Based on ANOVA results, the variables of $X_{1}, X_{2}$, $\mathrm{X}_{3}$ and $\mathrm{X}_{4}$ has no interaction for all factors. Based on ANOVA results variables of $X_{1}, X_{2}, X_{3}$ and $X_{4}$, as well as an interaction between $\mathrm{X}_{2}-\mathrm{X}_{3}, \mathrm{X}_{2}-\mathrm{X}_{4}$,linear form of $\mathrm{X}_{2}$ and $\mathrm{X}_{3}$ contributed significantly for response of $\mathrm{Y}_{6}(\mathrm{P}<0.05)$.

$\mathrm{Y}_{5}=4.77 \times 10^{-1}+8.64 \times 10^{-3} \mathrm{X}_{1}+5.83 \times 10^{-3} \mathrm{X}_{2}-0.61 \mathrm{X}_{3}+1.30 \times 10^{-3} \mathrm{X}_{4}$ (Eq. 5) (Adj. $\mathrm{R}^{2}$ of 0.3602 )

$\mathrm{Y}_{6}=5.53 \times 10^{-1}+1.00 \times 10^{-4} \mathrm{X}_{1+} 5.7 \times 10^{-3} \mathrm{X}_{2+} 4.25 \times 10^{-2} \mathrm{X}_{3-} 1.77 \times 10^{-3} \mathrm{X}_{4}$ (Eq. 6)

(Adj. $\mathrm{R}^{2}$ of 0.9425 ).

Fig. 6 and fig. 7 showed the contour plot along with along with 3D surface graph of tailing factor of A07 and SII. 


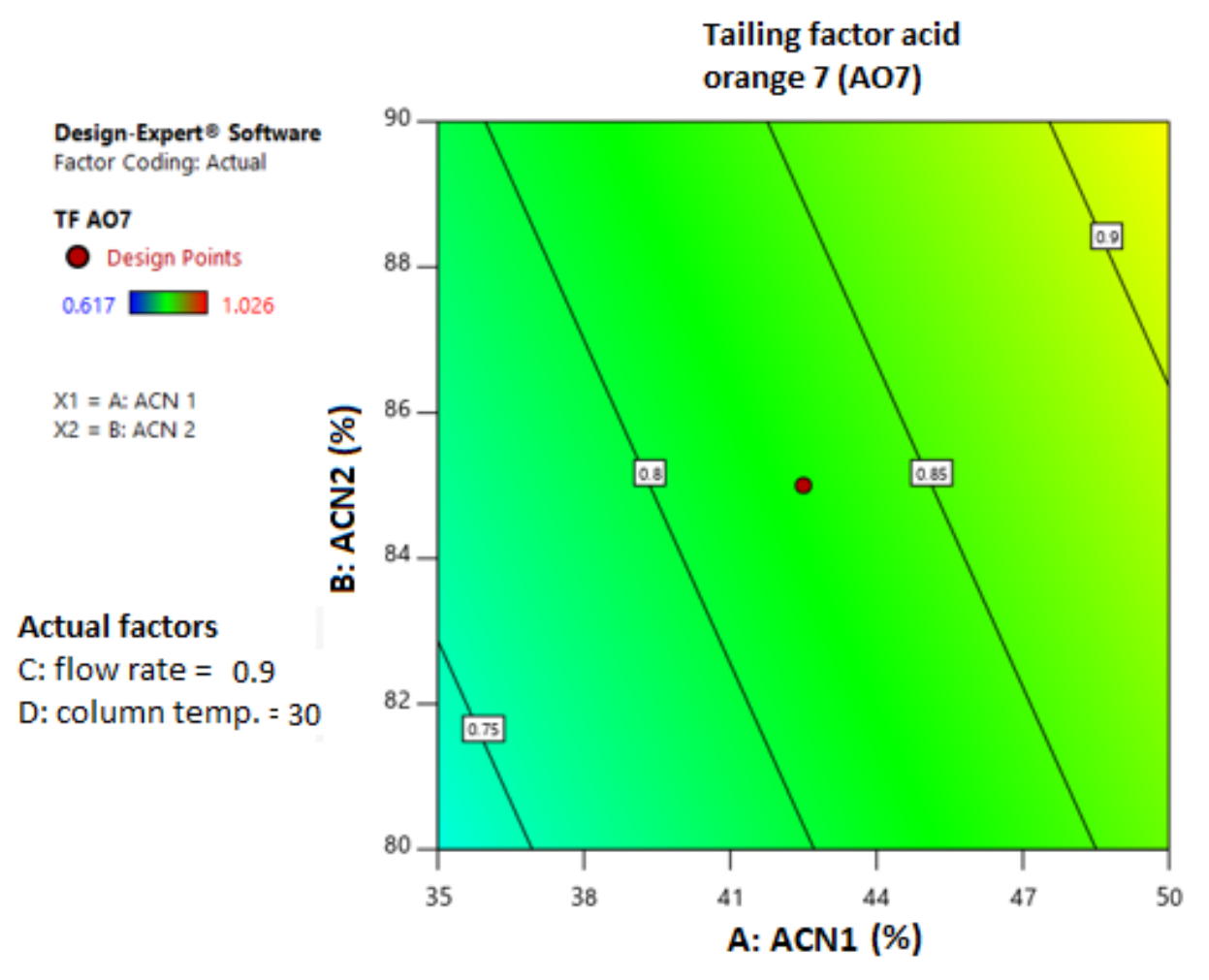

[A]
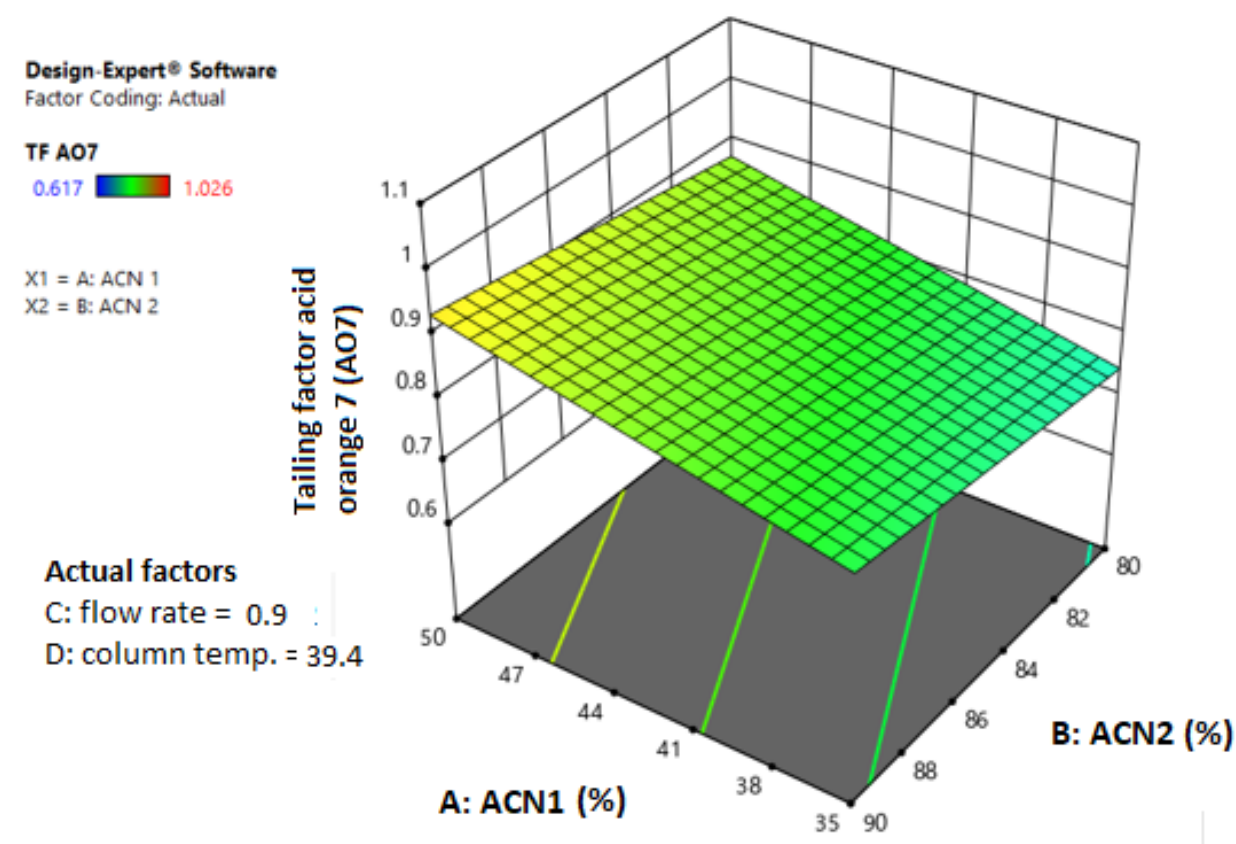

Actual factors

C: flow rate $=0.9$

D: column temp. $=39.4$

[B]

Fig. 6: The contour plot of tailing factor of acid orange 7 (A07) [A] and 3D surface graph [B] as a results of variables of the concentration of acetonitrile 1 (\%) (ACN1), the concentration of acetonitrile 2 (\%) (ACN2), flow rate and column temperature

The optimum predicted conditions for separation AO7 and SII based on statistical results were as follows: ACN1 43\%, ACN2 90\%, flow rate of $0.9 \mathrm{ml} / \mathrm{min}$ and column temperature of $40{ }^{\circ} \mathrm{C}$ with the desirability of 0.818 . It means that $81.80 \%$ data can be described by the selected model, the desired response would be reached easily [22]. The HPLC chromatogram obtained using this condition was shown in fig. 8. It is clear that both A07 and SII were clearly separated using optimum condition suggested by BBD. 


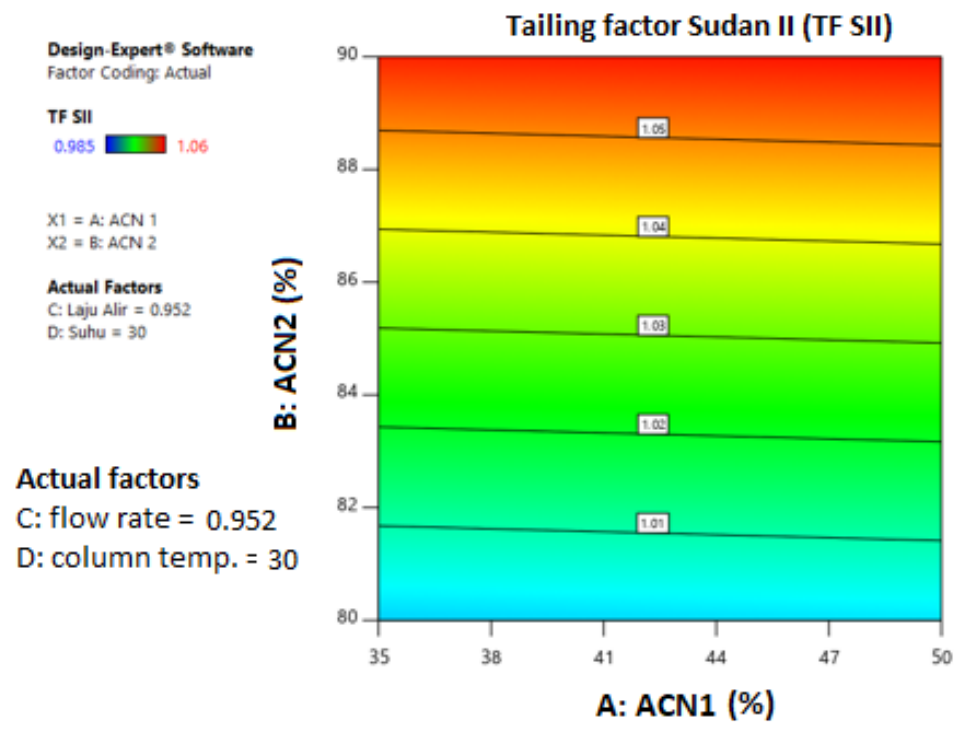

[A]

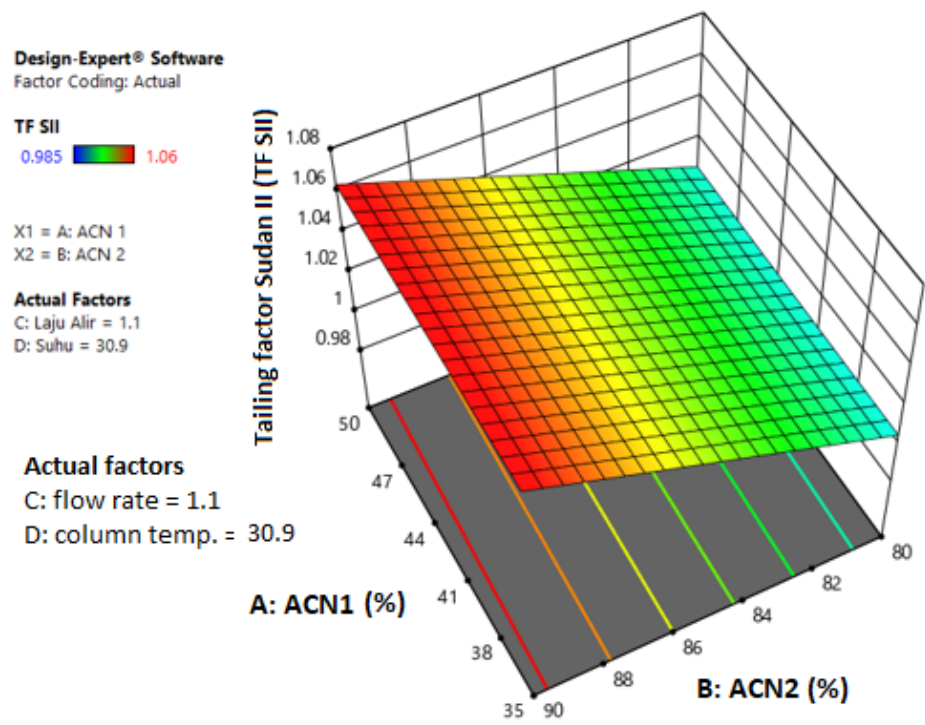

[B]

Fig. 7: The contour plot of tailing factor of sudan II (SII) [A] and 3D surface graph [B] as a results of variables of the concentration of acetonitrile 1 (\%) (ACN1), the concentration of acetonitrile 2 (\%) (ACN2), flow rate and column temperature

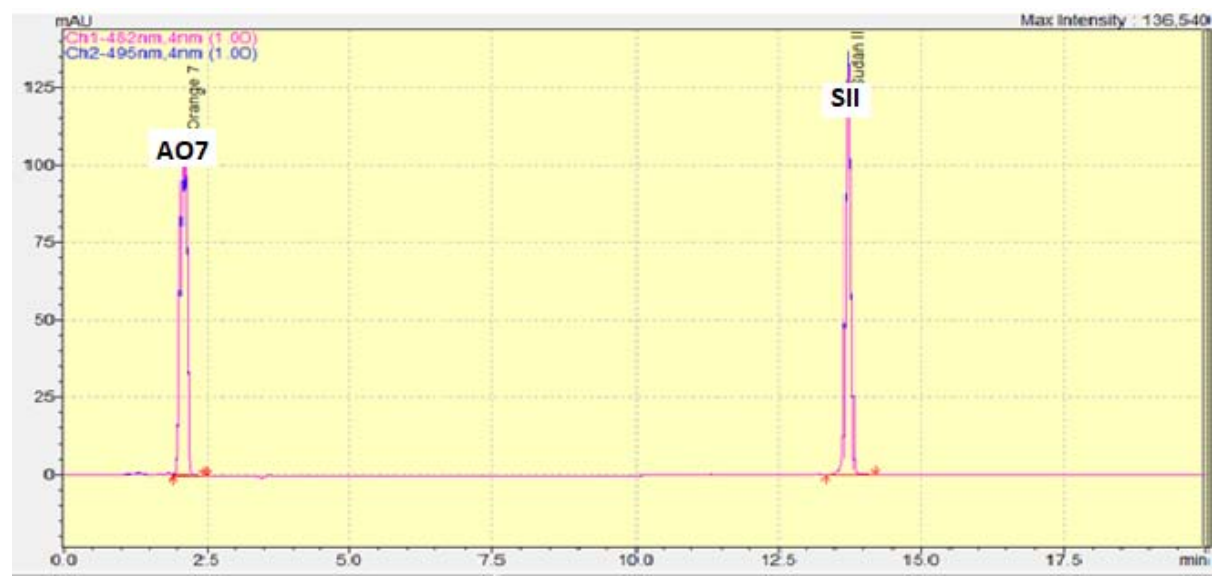

Fig. 8: Separation of acid orange 7 (AO7) and sudan II (SII) using HPLC condition as suggested by box-behnken design. See text for HPLC condition 


\section{CONCLUSION}

BBD design can be used to get optimum condition for analysis of A07 and Sudan II in blusher product. The optimum conditions suggested for separation AO7 and SII based on BBD was mobile phase containing ACN1 43\% and ACN2 90\% with flow rate of 0.9 $\mathrm{ml} / \mathrm{min}$, with column temperature of $40{ }^{\circ} \mathrm{C}$.

\section{ACKNOWLEDGMENT}

The author acknowledge to Indonesian National Agency of Drug and Food Control, Indonesian National Agency of Drug and Food Control in Denpasar, Indonesian National Agency of Drug and Food Control in Yogyakarta for financial support and instrument facilities.

\section{AUTHORS CONTRIBUTIONS}

NBRP performed research activity, compiled data, and prepared manuscript. AR and SM designed research activities, prepared manuscript and made critical thinking on the manuscript.

\section{CONFLICT OF INTERESTS}

The authors have declared "no conflicts of interest with respect to the research, authorship, and/or publication of this article".

\section{REFERENCES}

1. Kanekar H, Khale A. Coloring agents: a current regulatory perspective for coloring agents intended for pharmaceutical and cosmetic use. Int J Pharm Phytopharmacol Res 2014;2:1-20.

2. Rebane $R$, Leito I, Yurchenko $S$, Herodes K. A review of analytical techniques for determination of sudan I-IV dyes in food matrixes. J Chromatogr A 2010;1217:2747-57.

3. Barot J, Bahadur A. Toxic impacts of C. I. acid orange 7 on behavioural, haematological and some biochemical parameters of labeo rohita fingerlings. Int J Sci Res Environ Sci 2015;3:284-90.

4. Pan H, Feng J, Cerniglia CE, Chen H. Effects of orange II and sudan III azo dyes and their metabolites on Staphylococcus Aureusi. J Industr Microb Biotechnol 2011;38:1729-38.

5. Anfossi L, Baggiani C, Giovannoli C, Giraudi G. Development of enzyme-linked immunosorbent assays for sudan dyes in chilli powder, ketchup and egg yolk. Food Addit Contam 2009;26:800-7.

6. Di Anibal CV, Odena M, Ruisánchez I, Callao MP. Determining the adulteration of spices with Sudan I-II-II-IV dyes by UVvisible spectroscopy and multivariate classification techniques. Talanta 2009;79:887-92.

7. Lohumi S, Josh R, Kandpal LM, Lee H, Kim MS, Cho H. Quantitative analysis of sudan dye adulteration in paprika powder using FTIR spectroscopy. Food Addit Contam Part A 2017;34:678-86.

8. Schwack W, Pellissier E, Morlock G. Analysis of unauthorized sudan dyes in food by high-performance thin layer chromatography. Anal Bioanal Chem 2018;410:5641-51.
9. He L, Su Y, Fang B, Shen X, Zeng Z, Liu Y. Determination of sudan dye residues in eggs by liquid chromatography and gas chromatography-mass spectrometry. Anal Chim Acta 2007;594:139-46.

10. Zhao S, Yin J, Zhang J, Ding X, Wu Y, Shao B. Determination of 23 dyes in chili powder and paste by high-performance liquid chromatography-electrospray ionization tandem mass spectrometry. Food Anal Methods 2012;5:1018-26.

11. Cornet V, Govaert Y, Moens G, Van Loco J, Degroodt JM. Development of a fast analytical method for the determination of sudan dyes in chili and curry containing foodstuffs by high performance liquid chromatography-photodiode array detection. J Agric Food Chem 2006;54:639-44.

12. Ertas E, Ozer H, Alasalvar C. A rapid HPLC method for determination of sudan dyes and para red in red chilli pepper. Food Chem 2007; 105:756-60.

13. Van Bommel MR, Berghe IV, Wallert AM, Boitelle R, Wouters J. High-performance liquid chromatography and non-destructive three-dimensional fluorescence analysis of early synthetic dyes. J Chromatogr A 2007;1157:260-72.

14. Abbott LC, Batchelor SN, Smith JRL, Moore JN. Reductive reaction mechanisms of the azo dye orange II in aqueous solution and in cellulose: from radical intermediates to products. J Phys Chem A 2009;113:6091-103.

15. Rejczak T, Tuzimski T. Application of high-performance liquid chromatography with diode array detector for simultaneous determination of 11 synthetic dyes in selected beverages and foodstuffs. Food Anal Methods 2017;10:3572-88.

16. Shaji J, Shah A. Optimization of tenoxicam loaded niosomes using quadratic design. Int J Curr Pharm Res 2016;8:67-62.

17. Khanam N, Alam MI, Iqbal QMA, Ali MY, Siddiqui AR. A review on optimization of drug delivery system with experimental designs. Int J Appl Pharm 2018;10:12-7.

18. Siregar C, Prabaningdyah NK, Choiri S, Riyanto S, Rohman A. Optimization of HPLC using central composite design for determination of curcumin and demethoxycurcumin in tablet dosage form. Dhaka Univ J Pharm Sci 2018;16:137-45.

19. Setyawan EH, Setyowati EP, Rohman A, Nugroho AK. Central composite design for optimizing extraction of EGCG from green tea leaf (Camellia sinensis L.). Int J Appl Pharm 2018;10:211-6.

20. Bezerra MA, Santelli RE, Oliveira EP, Villar LS, Escaleira LA. Response surface methodology (RSM) as a tool for optimization in analytical chemistry. Talanta 2008;76:965-77.

21. Qiu P. Application of box-behnken design with response surface methodology for modeling and optimizing ultrasonic oxidation of arsenite with H2O2. Carr Eur J Chem 2014;12:172-64.

22. Sadhukhan B, Mondal NK, Chattoraj S. Optimisation using central composite design (CCD) and the desirability function for sorption of methylene blue from aqueous solution onto lemna major. Karbala Int J Modern Sci 2016;2:155-45. 